\title{
Fishers' ecological knowledge of smalleye hammerhead, Sphyrna tudes, in a tropical estuary
}

\author{
Vinicius J. Giglio ${ }^{1}$ and Hugo Bornatowski²
}

Coastal hammerheads have suffered from overexploitation and environmental degradation. We interviewed 79 artisanal fishers to verify fishery aspects, temporal changes in catches and biological aspects of the smalleye hammerhead, Sphyrna tudes, in a marine protected area on Abrolhos Bank, Brazil. Data were compared between three generations of fishers: young, middle-aged and old. Fishers' age varied between 17 and 88 years. We verified significant reductions in the weight of individuals caught by younger fishers. The main types of fishing gear used to catch $S$. tudes were gill nets and longlines. Overfishing through gill nets and trawl fisheries were mentioned as the cause of $S$. tudes population collapse in the region. The shark's diet as reported by fishers consisted of fish, crab and shrimp; austral summer was the reproductive season. A strong similarity was verified between fishers' knowledge and biological data. We suggest as plausible strategies to conserve the local population of $S$. tudes the reduction of net fisheries impact through zoning and establishment of no take areas. These steps can help to initiate the recovery of this depleted species.

Tubarões martelo costeiros têm sofrido com a sobrepesca e degradação ambiental. Foram entrevistados 79 pescadores artesanais para verificar aspectos da pesca, mudanças temporais nas capturas e aspectos biológicos de Sphyrna tudes em uma área marinha protegida no Banco dos Abrolhos, Brasil. Os dados foram comparados entre três gerações de pescadores: novos, meia idade e mais velhos. A idade dos pescadores variou entre 17 e 88 anos. Verificaram-se reduções significativas no peso dos indivíduos capturados pelos pescadores mais jovens. Os principais petrechos usados para captura de $S$. tudes foram redes de emalhe e espinhel. Pescadores mencionaram que o colapso da população local de $S$. tudes foi decorrente do excessivo uso de redes de emalhe e pelas pescarias de arrasto. A dieta reportada foi peixes, caranguejos e camarões e a época de reprodução foi o verão. Uma forte similaridade foi verificada entre o conhecimento dos pescadores e dados biológicos. São sugeridas como estratégias plausíveis para conservar a população local de $S$. tudes a redução do esforço das pescas com rede através de zoneamento e estabelecimento de áreas de exclusão de pesca. Esses passos podem ajudar a iniciar a recuperação de espécies depletadas.

Keywords: Abrolhos Bank, Artisanal fishing, Coastal shark, Elasmobranch, Fisheries management.

\section{Introduction}

The golden hammerhead shark, Sphyrna tudes (Valenciennes, 1822) is the smallest of hammerhead species (Carcharhiniformes: Sphyrnidae), reaching a total length (TL) of $150 \mathrm{~cm}$ (Castro, 1989). It is widely distributed throughout coastal waters of the southwest Atlantic, the Mediterranean Sea, and the eastern Pacific (Castro et al., 1999). In Brazil, this species is more common in the north and northeastern regions (Gadig, 2001).
Historically, S. tudes was considered to be a common fishing resource in some regions, such as South America (Castro, 1989). However, there are reports of a marked decline in the species population throughout its range. This decline was caused primarily by gill nets, which are considered to be very effective in catching $S$. tudes, even the smallest of them (Castro et al., 1999; Brasil, 2014). Sphyrna tudes is known to inhabit shallow coastal waters over muddy bottoms, such as mangroves and estuaries, at depths ranging between 9 and $40 \mathrm{~m}$ (Castro, 1989). These

${ }^{1}$ Universidade Federal do Rio de Janeiro, Programa de Pós-Graduação em Ecologia, Caixa Postal 68020, $21941-902$ Rio de Janeiro, RJ, Brazil.vj.giglio@gmail.com (corresponding author)

${ }^{2}$ Instituto de Pesca, Divisão de Pesca Marítima. Avenida Bartolomeu de Gusmão, 192, Aparecida, $11045-401$ Santos, SP, Brazil. anequim.bio@gmail.com 
habitats are among the most impacted by human activities because of their proximity with human populations (McCauley et al., 2015). Globally, coastal shark populations have suffered from overexploitation because they inhabit areas where fishing pressure is typically high (Robbins et al., 2006; Heupel et al., 2009; Bornatowski et al., 2011). In Brazil, for instance, populations of several commercially important species have been drastically reduced (e.g. Vooren \& Klippel, 2005). Moreover, S. tudes has a limited reproductive capacity with a litter size of 5 to 12 pups (Castro, 1989; Lessa et al., 1998), making it more susceptible to fishing pressure (Castro et al., 1999; Brasil, 2014). Thus, quantitative evaluation of gill net catches across its range is considered to be a priority by the International Union for Conservation of Nature (IUCN) which lists the species as vulnerable in its Red List of Threatened Species (Mycock et al., 2006).

In Brazil, $S$. tudes was not included in the endangered species list until December 2014, when it was listed as Critically Endangered. Over the past 10 years, there have been no records of the occurrence of the species in six Brazilian states (Brasil, 2014). In eastern Brazil, elder and middle-aged fishers have reported a decline in its abundance (Giglio et al., 2015). Also, low levels of genetic diversity were verified in northeastern region, suggesting that populations of $S$. tudes have suffered a marked decline (Tavares et al., 2013). Based on this information, specialists inferred that populations of this species have declined at least $80 \%$ in Brazilian waters (Brasil, 2014). The urgent management intervention recommended was the control of the gill net fleet in northern region as well as the establishment of no-take coastal marine protected areas (MPAs) (Brasil, 2014). Data on landings of S. tudes and even on its basic life history traits in Brazil are scarce. The size of maturity and reproduction was investigated in northeastern Brazil (Lessa et al., 1998) and the genetic diversity described to northern region (Tavares et al., 2013). Other studies simply include this species in checklists (e.g. Sadowsky, 1967; Stride et al., 1992; Menni \& Lessa, 1998). Sphyrna tudes has the same problem as other hammerhead shark species, which are frequently listed together as "hammerhead sharks" (Bornatowski et al., 2014).

An alternative method that can be used to overcome constraints imposed by limited data sets is to tap into the memories of fishers (Venkatachalam et al., 2010). The use of local ecological knowledge (LEK) has been widely used in surveys for data-poor or highly endangered species, especially in developing countries (e.g. Gerhardinger et al., 2009; Turvey et al., 2010; Leeney, 2015). Elder fishers can serve as a unique data source to inform science and management about changes in artisanal fisheries. In the present study, we investigated fishers' LEK to: (i) assess differencesin weight of $S$. tudes caught among generations of fishers, (ii) verify causes of species depletion, and (iii) provide data on reproduction and feeding of $S$. tudes. In addition, we propose strategies for the species conservation.

\section{Material and Methods}

Study site. The Abrolhos Bank is an enlargement of the continental shelf $\left(46,000 \mathrm{~km}^{2}\right)$ in the state of Bahia, eastern Brazil. It comprises the richest reef complex of the South Atlantic (Leão \& Kikuchi, 2001) and encompasses a mosaic of habitats, including beaches, rocky and coralline reefs, mangrove swamps, and vegetated sandbanks, that supports a high level of biodiversity (Leão \& Kikuchi, 2001). The research was conducted with fishers of a sustainable use marine protected area - MPA of the Abrolhos Bank, the Cassurubá Extractive Reserve (CER; 100,687 ha). The CER was created in 2009 and covers coastal habitats and the largest estuarine complex of the Abrolhos Bank (Fig. 1). Approximately 4,000 people work with artisanal fisheries in the CER (Pereira et al., 2013). About a quarter of these fishers use fishing gears capable of catching $S$. tudes: gill nets, trawl nets, hook and line, and longlines (Dapper et al., 2010). The fishing fleet of CER is composed of small motorized boats (6-20 m trawler), sail-boats and row boats (Giglio et al., 2015). The main resources of CER fishers are crabs, shrimp, snooks, snappers, croakers and the Brazilian mojarra, Eugerres brasilianus (Giglio \& Freitas, 2013). In the adjacent coastal reefs, studies have verified evidences of overexplotation among commercially important and endangered fishes, such as snappers and groupers (Freitas et al., 2011a, 2011b, 2014, 2015).

Data collection and analysis. We interviewed a total of 79 artisanal fishers with ages ranging between 17 and 88 years, in two municipalities and eight riverine fishing villages between March 2009 and September 2010. These fishers work in the estuarine and coastal regions of the CER. Fishers were interviewed through a structured questionnaire that contained the following questions: (1) age; (2) already caught $S$. tudes?; (3) weight of largest $S$. tudes ever caught; (4) which fishing gear caught $S$. tudes?; (5) what are the causes of $S$. tudes depletion?; (6) where do $S$. tudes live?; (7) food items of $S$. tudes; and (8) what is the reproductive season of this species? Questionnaires were individually applied to avoid influence of other fishers in the responses. Interviews were conducted randomly, in fishers' households, fish markets and associations. Before the interview, we explained the survey objectives and requested their consent to conduct the interview.

In order to ensure a representative sample, interviews followed Bunce et al. (2000) protocol, which recommends a range varying between 5 and $35 \%$ of the $S$. tudes fishers' in each of the communities visited. We considered $S$. tudes fishers' to be restricted to those using fishing gear that could catch the species. Before starting the interviews, we showed colored photos of $S$. tudes and S. lewini. Sphyrna tudes is regionally named by fishers as "panã amarela" because of its yellow-colored pattern. Photos of S. lewini were used as a control to verify that the identification of $S$. tudes was correct. We used the variable weight as 
a metric for body size because fishers usually sell fish by kilogram, and landed fish of greater body weight are usually embedded in the memory of the fishers (Giglio et al., 2015).

Respondents were grouped by age into three categories corresponding to generations: young (15-30 years, $\mathrm{n}=21)$, middle-aged ( $31-54$ years, $n=33)$ and old $(\geq 55$ years, $n=25$ ). To verify changes in the maximum body size among catches of $S$. tudes experienced across generations, differences among age groups were tested using non-parametric analysis of variance (Kruskal-Wallis test). Statistical tests were conducted at a significance level of $\mathrm{p}<0.05$.

\section{Results}

Fishers mentioned four types of fishing gear used to catch $S$. tudes: gill nets, longlines, hook and line and "ponta de linha" - a type of fishing gear that consists of a hook and line anchored to the bottom and marked at the surface with a buoy (Fig. 2). Thirty-five per cent of fishers used only one type of fishing gear to catch the species. Old and middleaged fishers reported an average of two types of fishing gear, while young reported less than two fishing gears (average $=1.7)$. Gill nets and longlines were the most cited types of fishing gear across generations. Gill nets were the first ranked type for middle-aged fishers, while longlines were the main types used by young and old fishers (Fig. 2).

The majority of old fishers had caught $S$. tudes during their lifetime (Fig. 3a), but most middle-aged and young fishers had not. The relationship between the largest individual of $S$. tudes caught and the fisher's age class revealed a declining trend towards young fishers, who mentioned the lowest weights (mean $\pm \mathrm{SE}=7 \pm 0.75 \mathrm{~kg} ; \mathrm{H}=$ $12.32, \mathrm{p}<0.01$ ), while middle-aged obtained a mean of 11.7 $\pm 0.29 \mathrm{~kg}$, and old fishers obtained a mean of $11.3 \pm 0.36 \mathrm{~kg}$ (Fig. 3b).

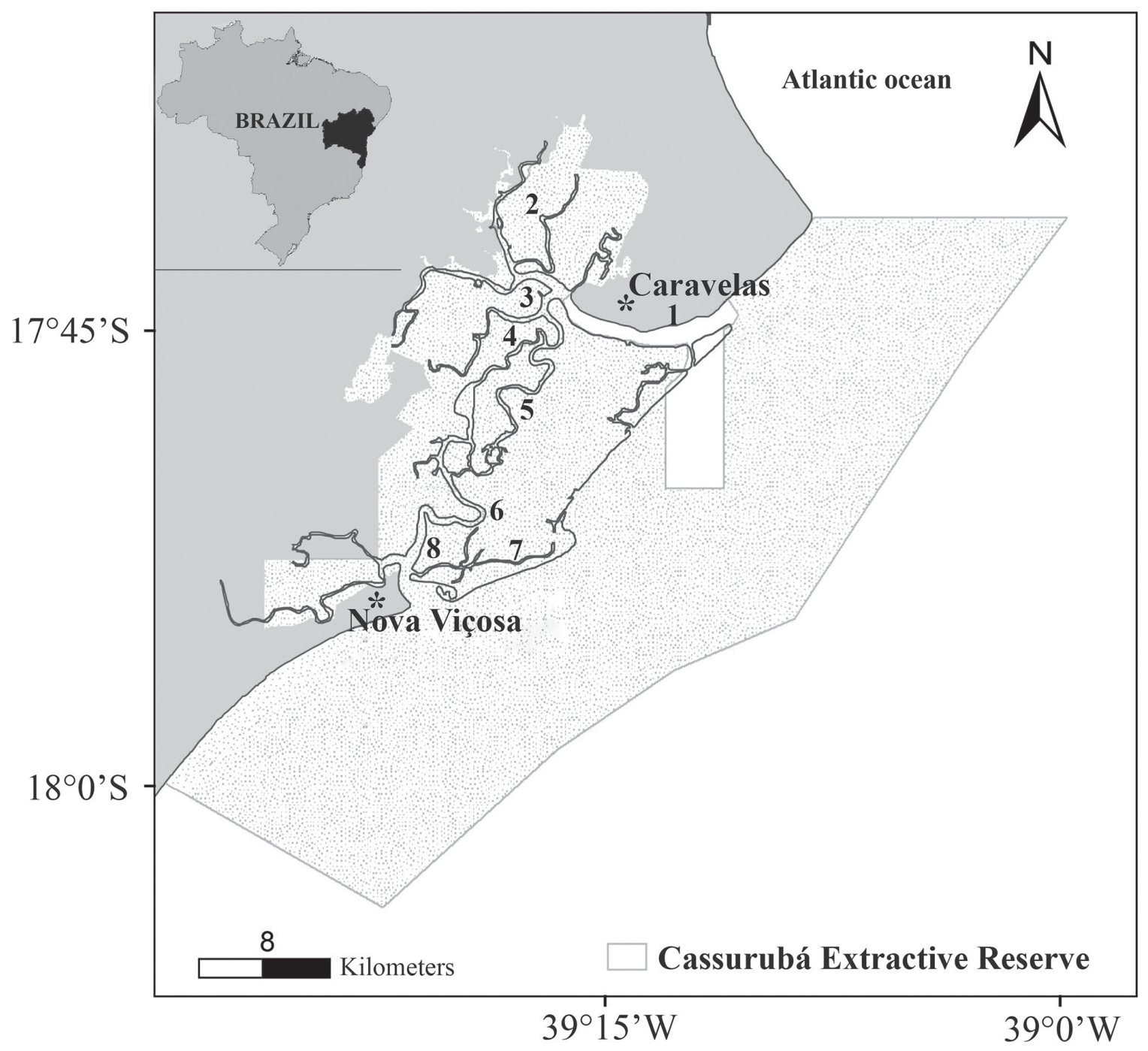

Fig. 1. Location of Cassurubá Extractive Reserve, Abrolhos Bank, eastern Brazil. Numbers represent fishing villages where fishers were interviewed. Caravelas city: 1- Barra $(n=16), 2$ - Massangano $(n=8)$, 3- Calabouço $(n=6), 4$ - Tapera $(n=8)$, 5- Caribê $(n=12)$. Nova Viçosa city: 6- Peróba $(n=12)$, 7- Barra Velha $(n=11)$ and 8- Tranqueira $(n=6)$. 


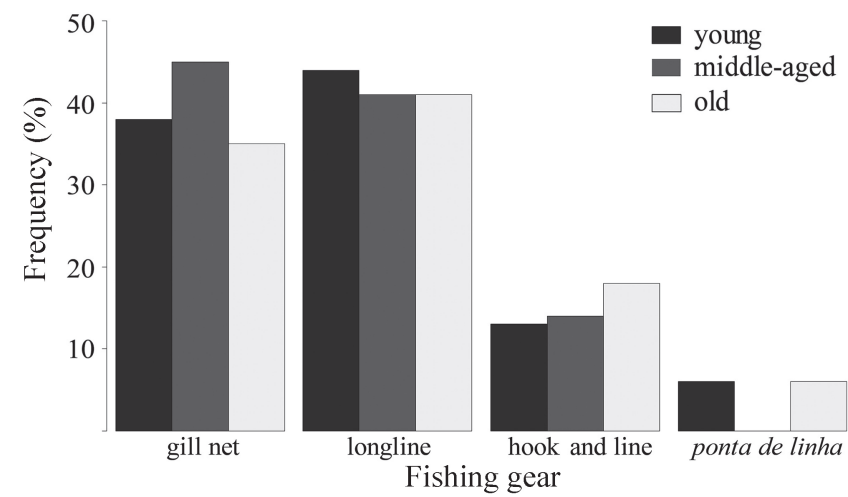

Fig. 2. Fishing gear used to catch Sphyrna tudes in Cassurubá Extractive Reserve, eastern Brazil.
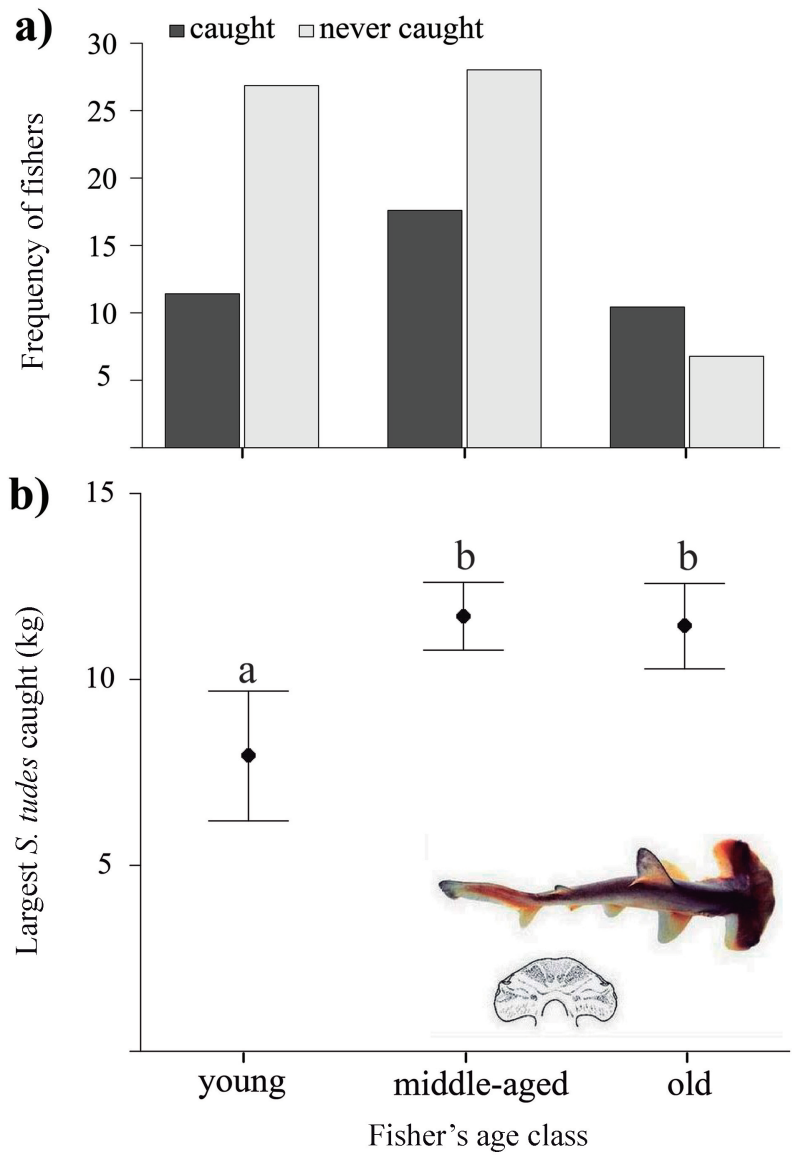

Fig. 3. (a) Number of fishers that had already caught Sphyrna tudes, distributed over fishers' generations on Abrolhos Bank; (b) Mean weight (+95\% CI) of Sphyrna tudes caught over three generations of fishers. Different letters above bars indicate significant differences $(\mathrm{p}<0.05)$.

Sites where $S$. tudes occurred were primarily estuaries and coastal areas $(61 \%)$. Some fishers stated that the species occurs in the open sea, outside of coastal areas (24\%). Mentioned food items included fish $(68 \%)$, crustaceans (21\%), and marisco (11\%) - a common name for zoobenthic invertebrates, such as crustaceans and molluscs (Fig. 4). The most cited fish were catfish (Arius spp.) and the
Brazilian snapper (Lutjanus alexandrei). Other fish were mullets (Mugil spp.), the Brazilian batfish (Ogcocephalus vespertilio), lane snapper (Lutjanus synagris), mojarras (Eugerres spp.) and soles (family Paralichthyidae).

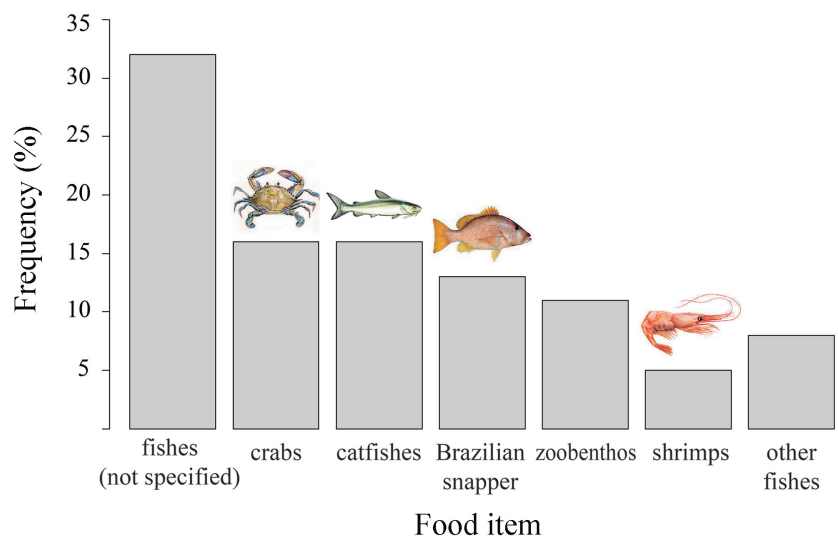

Fig. 4. Food items consumed by Sphyrna tudes according to fishers' local ecological knowledge of Cassurubá Extractive Reserve, eastern Brazil.

Regarding the causes of decline in abundance, all fishers agreed that $S$. tudes has indeed suffered a decline, with no records over the past 5 years. A total of seven causes for depletion were mentioned by $63 \%$ of fishers (Table 1 ). The excessive effort of gill nets and trawl fisheries were the most mentioned by all generations. Young fishers cited migration as the second main cause of the decline in $S$. tudes abundance (Table 1).

Nearly $78 \%(n=29)$ of fishers identified a reproductive season for $S$. tudes. Of these, $82 \%$ agreed that the species reproduces during the austral summer (January to March). Two elder fishers reported that pregnant $S$. tudes were caught with more than 10 puppies which were linked to the mother by an umbilical cord during the austral summer.

Table 1. Causes of decline in abundance for Sphyrna tudes mentioned by fishers in Cassurubá Extractive Reserve, Brazil. The question was answered by $62 \%$ of the fishers. Values are given as a percent of the total of fisher interviewed in each age group.

\begin{tabular}{lccc}
\hline $\begin{array}{l}\text { Cause of } \boldsymbol{S} \text {. Tudes } \\
\text { depletion }\end{array}$ & Young $(\mathrm{n}=11)$ & Middle-aged $(\mathrm{n}=24)$ & Old $(\mathrm{n}=15)$ \\
\hline gill net & 18 & 39 & 40 \\
trawl fishery & 27 & 22 & 30 \\
longline & 9 & 6 & 10 \\
river silting & 9 & 11 & 10 \\
migration & 18 & 6 & 0 \\
pollution & 9 & 11 & 10 \\
\hline
\end{tabular}

\section{Discussion}

By assessing fishers' LEK, this study reveals changes in the weight of $S$. tudes catches over the generations of fishers. Most younger fishers have never caught the 
species during their lifetime, and those who have caught one, report a weight significantly lower than old and middle-aged fishers. In a region that has experienced environmental change, younger generations may have less awareness of the diversity and abundance of species in the recent past. In the same region, Giglio et al. (2015) verified a marked depletion of megafauna and suggested the occurrence of the shifting baseline syndrome among fishers. The overexploitation of apex and mesopredators by artisanal fishing has been a cause of concern for managers of the Abrolhos Bank (Moura et al., 2013). Commercially important reef fishes have been exploited at the maximum effort level, and the stocks have declined (Freitas et al., 2011b; Bender et al., 2013).

Small hammerhead sharks have been depleted in coastal zones around the world. Examples include the extirpation of scoophead, S. media, and the bonnethead, S. tiburo, in Central and Southern Mexican Pacific (Pérez-Jiménez, 2014), the collapse of S. tiburo (Reis-Filho et al., 2014) and $S$. tudes populations in Brazil (Brasil, 2014). These species are susceptible to overfishing because of their life-history traits and the growing use of gill nets and trawls along the coastal zones (Castro, 1989; Lessa et al., 1998; Brasil, 2014). Sphyrna tudes was listed globally as Vulnerable and in Brazilian waters as Critically Endangered. In addition, the increasing rarity of the species as verified across the generations of fishers suggests the need for urgent management interventions.

The excessive effort of gill nets and trawl fisheries were pointed to as the main causes of the decline of $S$. tudes. There was an overall concern among fishers regarding the impacts of increases in fishing effort and the popularization of gill nets (Giglio et al., 2015). This gear is acknowledged as the most efficient to catch $S$. tudes during all life stages (Castro, 1989). Small coastal sharks are victim of artisanal fisheries because they are frequently captured by gill nets as secondary target species (Bornatowski et al., 2014). For instance, the Brazilian sharpnose shark, Rhizoprionodon lalandii, accounted for about $60 \%$ of the total shark landings from small-scale fisheries off southeastern and southern Brazil (Motta et al., 2005). These nets target commercially important species such as the acoupa weakfish, Cynoscion acoupa, Serra Spanish Mackerel, Scomberomorus brasiliensis, whitemouth croaker, Micropogonias furnieri and snooks (Centropomus spp.) (Isaac et al., 2009; Mendonça \& Pereira, 2014).

Longline were considered to be as effective as gill nets to catch $S$. tudes. However, they were less cited than gill nets as the main determinant in the abundance reduction of the species. Longlines are used less frequently, and the total fishing effort associated with longlines in Abrolhos Bank is lower than that of gill nets (Dapper, 2010). These nets were considered to be the main cause of fish species depletion in the region (Giglio et al., 2015).

There are no surveys indicating that levels of sediment accumulation in the estuarine rivers of Abrolhos Bank could be a cause of $S$. tudes population declines. However, coastal endeavors such as dredging, port construction, coastal occupation, and monocultures have caused several ecologic and social changes in the coastal zone (Silva Júnior et al., 2012; Moura et al., 2013). These impacts were mentioned by fishers of all generations as a cause of the disappearance of $S$. tudes. The dredging of a navigation channel near the estuary was acknowledged as the cause of river silting, which caused the species to migrate to other less impacted estuaries. Nevertheless, there are no biological data on the migration of coastal sharks caused by anthropogenic impacts. Coastal hammerhead sharks are resident within an estuary, but do not show site fidelity to specific areas (Heupel et al., 2006). Salinity (Ubeda et al., 2009) and prey abundance - crabs (Driggers III et al., 2014) - were the factors that influenced $S$. tiburo abundance. However, it is widely acknowledged that coastal sharks suffer from the impacts of fishing and environmental degradation (Ferretti et al., 2010). This is corroborated by the high number of endangered species along the coasts of all oceans (Dulvy et al., 2014).

Sphyrna tudes inhabits coastal zones; this characteristic was cited by all fishers. Four fishers caught the species along shallow reefs inside the extended continental shelf of Abrolhos Bank. Clearly, estuaries and estuarine-influenced coastal zones are the main habitat. Fishers stated that the species reproduces in mangroves, during the austral summer. Pregnant females were observed in northeast Brazil during the austral spring and summer (Lessa et al., 1998), which coincides with the one season verified by fishers.

The diet of $S$. tudes is composed of fishes, shrimps, crabs, squids and benthic crustaceans (Compagno, 1984; Cortés, 1999). Changes in the diet are related to ontogenic shifts, with juveniles feeding on shrimp and small crustaceans, and adults feeding on fishes and catfishes eggs (Castro, 1999). Fishers' LEK associated feeding preferences with stomach content and preferred baits. A high similarity was verified between food items described by this study and the literature, based on conventional ichthyological research. However, fishers did not recognize details of the change in diet according to life stage. Overall, fishers' LEK agreed with biological data. This reinforces that the approach can be useful to investigate aspects of coastal marine resources.

Middle-aged and old fishers mentioned weights of $S$. tudes caught up to $3 \mathrm{~kg}$ higher than described in the literature - $9 \mathrm{~kg}$ (Castro et al., 1989). One explanation for this discrepancy could be weight overestimation. It may also be that the largest individuals ever caught were greater than the weight described in the literature. In northeastern Brazil, Lessa et al. (1998) found the size at first maturity was $20 \mathrm{~cm}$ TL higher than in Trinidad. This suggests that Brazilian individuals can reach larger sizes than those of Trinidad.

In conclusion, we verified a significant decline trend in the weight of $S$. tudes caught by the younger 
fishers. Fishers' LEK suggested that overfishing by gill nets and trawls was the cause of $S$. tudes depletion in Abrolhos Bank. Since 2011, Brazil does not have a systematic monitoring program for artisanal fishing, and the shark data available are not reported at the species level (Bornatowski et al., 2014). These are basic data for fisheries management. Sphyrna tudes fishing was recently prohibited in Brazilian waters, but the endangered list was suspense. The implementation of a fishing ban is a challenge in the actual context of a lack of resources and political interest in conservation (Giglio et al., 2014; Di Dario et al., 2015). MPAs are claimed as a powerful tool to conserve coastal resident sharks, especially for those that use specific nursery, reproduction or feeding sites (Speed et al., 2010). Management strategies recommended to conserve coastal sharks are reduction of the fishing effort, reduction of by-catch mortality, implementation of spatial-seasonal closures and establishment of permanent closures in key areas (e.g. mating and nursery sites) (Myers $\&$ Worm, 2005). In this context, research on the habitat use, migration patterns and habitat partitioning is essential for developing successful management initiatives for the conservation of $S$. tudes. There is an urgent need of a management plan for Cassurubá Extractive Reserve. This plan should serve as a guide to conserve natural resources of this MPA. We suggest as plausible strategies to conserve $S$. tudes in Abrolhos Bank the reduction in gill net and trawl fisheries effort through zoning and seasonal closures, and the establishment and surveillance of no take areas. These steps can help to start the recovery of the increasing number of depleted species.

\section{Acknowledgements}

We thank H. Teixeira and P. Beckenkamp for support in data collection. Ecomar NGO for logistical support. This study was financed by the Fundação Biodiversitas. We thank the São Paulo Research Foundation (FAPESP Process number 2013/25930-0) for a scholarship to HB. We also thank J. Nienow and J. Muehlbauer for their comments which greatly improved the manuscript.

\section{References}

Bender, M. G., S. R. Floeter \& N. Hanazaki. 2013. Do traditional fishers recognize reef fish species declines? Shifting environmental baselines in Eastern Brazil. Fisheries Management and Ecology, 20: 58-67.

Bornatowski, H., R. R. Braga \& J. R. S. Vitule. 2014. Threats to sharks in a developing country: The need for effective and simple conservation measures. Natureza \& Conservação, 12: 11-18.

Bornatowski, H., J. R. S. Vitule, V. Abilhoa \& M. F. M. Corrêa. 2011. Unconventional fishing for large sharks in the State of Paraná, southern Brazil: a note of concern. Journal of Applied Ichthyology, 27: 1108-1111.
Brasil. 2014. Avaliação nacional do risco de extinção da fauna brasileira: peixes - Sphyrna tudes (Valenciennes, 1822) - tubarão-martelo. Available from: http://www.icmbio. gov.br/portal/biodiversidade/fauna-brasileira/lista-deespecies/6567-especie-6567.html. (15 Jun 2015).

Bunce, L., P. Townsley, R. Pomeroy \& R. Pollnac. 2000. Socioeconomic manual for coral reef management. Townsville: Global Coral Reef Monitoring Network, 251p.

Castro, J. I. 1989. The biology of the golden hammerhead, Sphyrna tudes, off Trinidad. Environmental Biology of Fishes, 24: 3-11.

Castro, J. I., C. M. Woodley \& R. L. Brudek 1999. A preliminary evaluation of the status of shark species. FAO Fisheries Technical Paper 380. Rome: FAO, 72p.

Compagno, L. J. V. 1984. FAO Species Catalogue. Vol. 4. Sharks of the World: An annotated and illustrated catalogue of shark species known to date. FAO Fisheries Synopsis, 125: 251-655.

Cortés, E. 1999. Standardized diet compositions and trophic levels of sharks. ICES Journal of Marine Science, 56: 707-717.

Dapper, C. G., V. J. Giglio \& H. Teixeira. 2010. Relatório de características da atividade pesqueira no extremo sul da Bahia - municípios de Prado, Alcobaça, Caravelas, Nova Viçosa e Mucuri.

Di Dario, F., C. B. M. Alves, H. Boos, F. L. Frédou, R. P. T. Lessa, M. M. Mincarone, M. A. A. Pinheiro, C. N. M. Polaz, R. E. Reis, L. A. Rocha, F. M. Santana, R. A. Santos, S. B. Santos, M. Vianna \& F. Vieira. 2015. A better way forward for Brazil's fisheries. Science, 347: 1079.

Driggers III, W. B., B. S. Frazier, D. H. Adams, G. F. Ulrich, C. M. Jones, E. R. Hoffmayer \& M. D. Campbell. 2014. Site fidelity of migratory bonnethead sharks Sphyrna tiburo (L. 1758) to specific estuaries in South Carolina, USA. Journal of Experimental Marine Biology and Ecology, 459: 61-69.

Dulvy, N. K., L. R. Harisson, J. K. Carlson, L. N. K. Davidson, S. V. Forfham, M. P. Francis, C. M. Pollock, C. A. Simpfendorfer G. H. Burgess, K. E. Carpenter, L. J. V. Compagno, D. A. Ebert, C. Gibson, M. R. Heupel, S. R. Livingstone, J. C. Sanciangco, J. D. Stevens, S. Valenti \& W. T. White. 2014. Extinction risk and conservation of the world's sharks and rays. eLIFE, 3: e00590.

Ferretti, F., B. Worm, G. L. Britten, M. R. Heithaus \& H. K. Lotze. 2010. Patterns and ecosystem consequences of shark declines in the ocean. Ecology Letters, 13: 1055-1071.

Freitas, M. O., V. Abilhoa, V. J. Giglio, M. Hostim-Silva, R. L. Moura, R. B. Francini-Filho \& C. V. Minte-Vera. 2015. Diet and reproduction of the goliath grouper, Epinephelus itajara (Actinopterygii: Perciformes: Serranidae), in Eastern Brazil. Acta Ichthyologica et Piscatoria, 45: 1-11.

Freitas, M. O., V. Abilhoa \& G. H. C. Silva. 2011a. Feeding ecology of Lutjanus analis (Teleostei: Lutjanidae) from Abrolhos Bank, Eastern Brazil. Neotropical Ichthyology, 9: 411-418.

Freitas, M. O., R. L. Moura, R. B. Francini-Filho \& C. V. MinteVera. 2011b. Spawning patterns of commercially important reef fish (Lutjanidae and Serranidae) in the tropical western South Atlantic. Scientia Marina, 75: 135-146. 
Freitas, M. O., G. R. A. Rocha, P. T. C. Chaves \& R. L. Moura. 2014. Reproductive biology of the lane snapper, Lutjanus synagris, and recommendations for its management on the Abrolhos Shelf, Brazil. Journal of the Marine Biological Association of the United Kingdom, 94: 1711-1720.

Gadig, O. B. F. 2001. Tubarões da costa brasileira. Unpublished $\mathrm{PhD}$ thesis. Universidade Estadual Paulista, Rio Claro, Brazil. $343 p$.

Gerhardinger, L. C., M. Hostim-Silva, R. P. Medeiros, J. Matarezi, A. A. Bertoncini, M. O. Freitas \& B. P. Ferreira. 2009. Fishers' resource mapping and goliath grouper Epinephelus itajara (Serranidae) conservation in Brazil. Neotropical Ichthyology, 7: 93-102.

Giglio, V. J., A. A. Bertoncini, B. P. Ferreira, M. Hostim-Silva \& M. O. Freitas. 2014. Landings of goliath grouper, Epinephelus itajara, in Brazil: despite prohibited over ten years, fishing continues. Natureza \& Conservação, 12: 118-123.

Giglio, V. J. \& M. O. Freitas. 2013. Caracterização da pesca artesanal com rede de camboa na Reserva Extrativista de Cassurubá, Bahia. Biotemas, 26: 249-259.

Giglio, V. J., O. J. Luiz \& L. C. Gerhardinger. 2015. Depletion of marine megafauna and shifting baselines among artisanal fishers in eastern Brazil. Animal Conservation, 18: 348-358.

Heupel, M. R., C. A. Simpfendorfer, A. B. Collins \& J. P. Tyminski. 2006. Residency and movement patterns of bonnethead sharks, Sphyrna tiburo, in a large Florida estuary. Environmental Biology of Fishes, 76: 47-67.

Heupel, M. R., A. J. Williams, D. J. Welch, A. Ballagh, B. D. Mapstone, G. Carlos, C. Davies \& C. A. Simpfendorfer. 2009. Effects of fishing on tropical reef associated shark populations on the Great Barrier Reef. Fisheries Research, 95: 350-361.

Isaac, V. J., R. V. E. Santo, B. Bentes, F. L. Frédou, K. R. M. Mourão \& T. Frédou. 2009. An interdisciplinary evaluation of fishery production systems off the state of Pará in North Brazil. Journal of Applied Ichthyology, 25: 244-255.

Leão, Z. M. A. N. \& R. K. P. Kikuchi. 2001. The Abrolhos reefs of Brazil. Pp. 83-96. In: U. Seelinger \& B. Kjerfve (Eds.). Coastal marine ecosystems of Latin America. Berlin, Springer-Verlag.

Leeney, R. H. 2015. Fishers' ecological knowledge of sawfishes in Lake Piso, Liberia. Aquatic Conservation: Marine and Freshwater Ecosystems, 26: 381-385. DOI: 10.1002/aqc. 2542.

Lessa, R., R. C. Menni \& F. Lucena. 1998. Biological Observations on Sphyrna lewini and S. tudes (Chondrichthyes, Sphyrnidae) from Northern Brazil. Vie Milieu, 48: 203-213.

McCauley, D. J., M. L. Pinsky, S. R. Palumbi, J. A. Estes, F. H. Joyce \& R. R. Warner. 2015. Marine defaunation: animal loss in the global ocean. Science, 347, DOI: 10.1126/ science. 1255641 .

Mendonça, J. T. \& A. L. C. Pereira. 2014. Management of gillnet fisheries in the south coast of the state of São Paulo, Brazil. Anais da Academia Brasileira de Ciências, 86: 1227-1237.

Menni, R. C. \& R. P. Lessa 1998. The chondrichthyan community off Maranhão (northeastern Brazil). II. Biology of species. Acta zoológica lilloana, 44: 69-89.
Motta, F. S., O. B. F. Gadig, R. C. Namora \& F. M. S. Braga. 2005. Size and sex compositions, length-weight relationship, and occurrence of the Brazilian sharpnose shark, Rhizoprionodon lalandii, caught by artisanal fishery from southeastern Brazil. Fisheries Research, 74: 116-126.

Moura, R. L., N. A. Secchin, G. M. Amado-Filho, R. B. FranciniFilho, M. O. Freitas, C. V. Minte-Vera, J. B. Teixeira, F. L. Thompson, G. F. Dutra, P. Y. G. Sumida, A. Z. Guth, R. M. Lopes \& A. C. Bastos. 2013. Spatial patterns of benthic megahabitats and conservation planning in the Abrolhos Bank. Continental Shelf Research, 70: 109-117.

Mycock, S. G., R. Lessa \& Z. Almeida. 2006. Sphyrna tudes. The IUCN Red List of Threatened Species. Available from: http://www.iucnredlist.org/ details/60202/0. (8 May 2015).

Myers, R. A. \& B. Worm. 2005. Extinction, survival or recovery of large predatory fishes. Philosophical Transactions of the Royal Society B: Biological Sciences, 360: 13-20.

Pereira, R., C. I. Donatti, R. Nijbroek, E. Pidgeon \& L. Hannah. 2013. Climate change vulnerability assessment of the Discovery Coast and Abrolhos Shelf, Brazil. Rio de Janeiro, Conservation International, $79 \mathrm{p}$.

Pérez-Jiménez, J. C. 2014. Historical records reveal potential extirpation of four hammerhead sharks (Sphyrna spp.) in Mexican Pacific waters. Reviews in Fish Biology and Fisheries, 24: 671-683.

Reis-Filho, J. A., C. L. S. Sampaio, L. Leite, G. S. A. Oliveira, M. Loiola \& J. A. C. C. Nunes. 2014. Rediscovery of bonnethead shark Sphyrna tiburo after more than two decades of nonrecord on central coast of Brazil. Marine Biodiversity Records, 7: e44.

Robbins, W. D., M. Hisano, S. R. Connolly \& J. H. Choat. 2006. Ongoing collapse of coral-reef shark populations. Current Biology, 16: 2314-2319.

Sadowsky, V. 1967. Selachier aus dem litoral von São Paulo, Brasilien. Beitrage zur Neotropischen Fauna, 5: 71-88.

Silva Júnior, D. R., S. R. Santos, M. Travassos \& M. Vianna. 2012. Impact on a fish assemblage of the maintenance dredging of a navigation channel in a tropical coastal ecosystem. Brazilian Journal of Oceanography, 60: 25-32.

Speed C. W., I. C. Field, M. G. Meekan \& C. J. A. Bradshaw. 2010. Complexities of coastal shark movements and their implications for management. Marine Ecology Progress Series, 408: 275-293.

Stride, R. K., V. S. Batista \& L. A. B. Raposo. 1992. Pesca experimental de tubarão com redes de emalhar no litoral maranhense. São Luís, Projeto Pesca Artesanal. CORSUP/ EDUFMA. 160p.

Tavares, W., L. F. S. Rodrigues-Filho, D. Sodré, R. F. C. Souza, H. Schneider, I. Sampaio \& M. Vallinoto. 2013. Multiple substitutions and reduced genetic variability in sharks. Biochemical Systematics and Ecology, 49: 21-29.

Turvey, S. T., L. A. Barrett, H. Yujiang, Z. Lei, Z. Xinqiao, W. Xianyan, H. Yadong, Z. Kaiya, T. Hart \& W. Ding. 2010. Rapidly shifting baselines in Yangtze fishing communities and local memory of extinct species. Conservation Biology, 24: $778-787$. 
Ubeda, A. J., C. A. Simpfendorfer \& M. R. Heupel. 2009. Movements of bonnetheads, Sphyrna tiburo, as a response to salinity change in a Florida estuary. Environmental Biology of Fishes, 84: 293-303.

Venkatachalam, A. J., A. R. G. Price, S. Chandrasekara, S. Senaratna Sellamuttu \& J. Kaler. 2010. Changes in frigate tuna populations on the south coast of Sri Lanka: evidence of the shifting baseline syndrome from analysis of fisher observations. Aquatic Conservation: Marine and Freshwater Ecosystems, 20: 167-176.
Vooren, C. M. \& S. Klippel. (Eds.). 2005. Ações para a conservação de tubarões e raias no sul do Brasil. Porto Alegre, Igaré, 261p.

Submitted July 15, 2015

Accepted February 04, 2016 by Fernando Gibran 